\title{
Gelidiella acerosa inhibits lung cancer proliferation
}

\author{
Fazeela Mahaboob Begum S.M. ${ }^{1}$, Kalai Chitra ${ }^{2}$, Benin Joseph², Raji Sundararajan ${ }^{3}$ and Hemalatha S. ${ }^{*}$
}

\begin{abstract}
Background: Lung adenocarcinoma is the most common subtype of Non small cell lung cancer in which the PI3K Akt cascade is frequently deregulated. The ubiquitous expression of the PI3K and the frequent inactivation of PTEN accounts for the prolonged survival, evasion of apoptosis and metastasis in cancer. This has led to the development of PI3K inhibitors in the treatment of cancer. Synthetic PI3K inhibitors undergoing clinical and preclinical studies are toxic in animals. Hence, there is a critical need to identify PI3K inhibitor(s) of natural origin.

The current study aims to explore the efficacy of the red algae Gelidiella acerosaon inhibition of cell proliferation, migration and the expression of cell survival genes in lung adenocarcinoma cell line A549.

Methods: The phytoconstituents of Gelidiella acerosa were extracted sequentially with solvents of different polarity, screened qualitatively and quantitatively for secondary metabolites and characterized by GC-MS. The in-vitro studies were performed to check the efficacy of the extract on cell proliferation (MTT assay), cell invasion (scratch assay and colony formation assay), apoptosis (fluorescent, confocal microscopy and flow cytometry) and expression of apoptosis and cell survival proteins including PI3K, Akt and GSK3 $\beta$ and matrix metalloproteinase MMP2 and MMP9 by Western blot method. The antitumor activity of GAE was analyzed in a tumor model of Zebrafish.

Results: The outcomes of the in vitro analysis showed an inhibition of cell proliferation, induction of apoptosis, inhibition of cell migration and colonization by the crude extract. The analysis of protein expression showed the activation of caspases 3 and Pro apoptotic protein Bax accompanied by decreased expression of Bcl-2 and Bcl-XL. On the other hand, subsequent activation of GSK3ß and down regulation of PI3K, Akt were observed. The decreased expression of MMP2 correlated with the antimetastatic activity of the extract. The in vivo studies showed an inhibition of tumor growth by GAE in Zebrafish.
\end{abstract}

Conclusion: The phytoconstituents of algal extract contributed to the anticancer properties as evidenced by in vitro and in vivo studies. These phytoconstituents can be considered as a natural source of PI3K/Akt inhibitor for treatment of cancers involving the PI3K cascade.

Keywords: Gelidiella acerosa, PI3K, Akt, GSK3ß, Caspase 3, Bax, Bcl-2, Bcl-XL, Tumor model of zebrafish

\section{Background}

Lung cancer is a heterogeneous disease which has taken a death toll of 1.6 million in 2015 [1]. The two major classes of lung cancer are Non Small cell lung cancer (NSCLC) and Small cell lung cancer. Of these, the NSCLC accounts for $85 \%$ of lung cancer cases. Histologically, NSCLC includes three subclasses, namely small cell carcinoma, large cell carcinoma and adenocarcinoma. Among these, the lung adenocarcinoma constitutes

\footnotetext{
* Correspondence: hemalatha.sls@bsauniv.ac.in

${ }^{1}$ School of Life Sciences, B.S. Abdur Rahman Crescent University, Chennai 600048 , India

Full list of author information is available at the end of the article
}

$40 \%$ of NSCLC cases [2]. The 5-year survival rate of NSCLC varies from 1 to $45 \%$, depending on the extent of metastasis. Molecular profiling studies have identified the PI3K/Akt cascade as a frequently targeted pathway in NSCLC $[3,4]$.

The phosphoinositide kinases 3 (PI3Ks) are groups of proteins that regulate cell growth, survival, metabolism and glucose homeostasis [5]. Recent studies have shown that PI3K and its components are frequently mutated in human cancers which in turn contribute to the aberrant activation of the PI3K/AKT/mTOR pathway in cancer. Hence, the PI3K cell survival pathway became the most 
targeted candidates for anticancer therapy $[5,6]$. Further, the aberrant expression of PI3K confers multidrug resistance, thus contributing to poor prognosis [7, 8]. Targeting the PI3K signaling cascade with small molecule inhibitors could be an effective means of treating cancer $[9,10]$. Current PI3K inhibitors that are available in the market act either by inhibiting PI3K or any of its downstream components [7-11]. The first generation PI3K inhibitors including Wortmannin and LY294002 were discontinued due to their toxicity in animals [12, 13]. Several PI3K inhibitors are being developed in both the pharmaceutical industries and academic institutions. These include the Dactolisib, Umralisib, Buparlisib, Serabelisib, IP1-549, SF-253, GDC-0326and Alpelisib which are undergoing different phases of clinical trials [14-22]. The recent approval of Idelalisib, the first oral PI3K inhibitor by the FDA for the treatment of chronic lymphocytic leukemia [23], has triggered the drug industry to search for new PI3K inhibitors that act efficiently and selectively without any side effects. Hence, the current study was intended to identify natural bioactives which can target PI3K or its components and without any cytotoxicity.

Natural products are used worldwide for the treatment of various diseases. Recent studies have shown that $47 \%$ of anticancer drugs are developed from natural products [24]. According to the World Health Organisation, 80\% of the world's population relies on natural products for health care. Over the past 40 years, the marine environment has drawn special attention due to the discovery of numerous lead compounds and drugs with unique structures [25]. Among the marine organisms, algae and sponges are widely utilized as sources of novel drugs. Marine red algae are rich in bioactive metabolites with varied therapeutic properties [26, 27]. They are widely exploited for the production of agar, alginates and carrageenan worldwide [28]. The marine red algae Gelidiella acerosa (G.acerosa) (Order: Gelidiales, Family: Gelidiellaceae, Genus: Gelidiella) is abundantly found in the intertidal zones of the Gulf of Mannar, South India. It is widely utilized by the Food and Pharma industries for its high-quality agar [29]. Studies conducted earlier have reported the antimicrobial, antioxidant, antifungal, anticoagulant, antifertility, anticholinesterase, anticancer and post-coital contraceptive activities of G.acerosa [30-40]. Although, the anticancer activity of the algae was reported previously [39] the phytocompounds and their mechanism of action were not reported. Our current research is focused on discovering the bioactive molecules from G.acerosa, which can target PI3K pathway and its components without inducing any cytotoxicity. Although enough medical advancement is achieved in the management of lung cancer, the survival rate is highly disappointing [41]. The frequent deregulation of PI3K and its components accounts for progression of lung cancer
[42]. The over-activation of PI3K confers resistance to the current anticancer therapies. Hence there is a critical need to identify a suitable drug which acts by inhibiting PI3K, Akt expression. In the current study, the phytoconstituents of G.acerosa are analyzed for their efficacy to inhibit cell proliferation, invasion and tumor formation, induction of apoptosis and regulation of cell survival cascade PIK3, Akt, GSK3 $\beta$ under in vitro conditions using the adenocarcinoma lung cancer cell line A549.

As per FDA regulations, acute and chronic toxicity studies are essential for compounds which are intended for human use. As most of the compounds which are effective under in vitro conditions, failed in toxicity analysis and in vivo studies, the current research was focused on determining the in vivo toxicity in adult Zebrafish (Danio rerio) and confirming the results through a novel Tissue-Chip technology.

\section{Methods}

Seaweed collection, processing and characterization

Marine red algae G.acerosa was collected from the Mandapam coast, Tamil Nadu, India after identification and authentication by Dr. Raju Saravanan, Scientist, Center for Marine Fisheries Research Institute (CMFRI), Mandapam, India. A specimen of the seaweed was deposited at CMFRI (accession number: MMM-CMFRI17002). The seaweed was washed, shade dried, milled and the dry powder was used for sequential extraction [43] and analyzed for the presence of various phytoconstituents $[44,45]$. The total polyphenol and flavonoids content of the extracts were estimated [46, 47]. The ethyl acetate extract of G.acerosa (GAE) was subjected to HPLC analysis [48] in Shimadzu HPLC 9A with LC 20 AD binary gradient pump, SPD- M20A Diode array detector and RF-Fluorescence detector. The identification of functional groups, covalent bonds in GAE was carried out through Fourier Transformation Infrared spectroscopy $[49,50]$. The GC MS analysis of GAE was done in JOEL GCMATE II GCMS advanced mass spectroscopy system. The sample was analyzed as per the manufacturer's protocol and the emerging fragment ions were collected. The probable structure based on the ion fragmentation pattern was derived from the NIST14 (National Institute of Standards and Technologies) library search.

\section{Determination of antioxidant activity 2, 2 Di phenyl - 1-Picrylhydrazyl (DPPH) radical scavenging assay}

The efficacy of the algal extracts to scavenge the free radicals generated in the form of (DPPH) was assessed as previously described [51]. 


\section{In vitro analysis of cell viability}

A549 cells, procured from National Facility for Animal Tissue and Cell Culture, Pune, India, were used for the study. The cells were subcultured in DMEM containing $10 \%$ heat-inactivated FBS and 1\% antibiotic cocktail (GIBCO, USA). The cell viability assay was carried out [52]. Briefly, $2 \times 105$ cells were seeded in 96 well plates and allowed to adhere. The cells were exposed to different concentrations of GAE $(0.1-2 \mathrm{mg} / \mathrm{ml})$ for $24 \mathrm{~h}$ and the cell viability was assessed by MTT assay.

\section{Analysis of apoptosis}

The hallmarks of apoptosis were analyzed by fluorescent and confocal microscopy. In brief, $2 \times 105$ cells were seeded in 6 well plates and allowed to become $80 \%$ confluent. The cells were exposed to $1.5 \mathrm{mg}$ of GAE for $24 \mathrm{~h}$. The cells were washed with ice-cold PBS twice and fixed with $70 \%$ ice-cold methanol and stained with DAPI $(5 \mu \mathrm{l})$ for $5 \mathrm{~min}$ in darkness. The cells were observed for nuclear fragmentation under the inverted fluorescent microscope (Zeiss1.0). The same procedure was followed for staining with propidium iodide $(5 \mathrm{mg} / \mathrm{ml})$ and AnnexinV $(5 \mu \mathrm{l})$. For Flow cytometry analysis, $5 \times 103$ cells were seeded in $35 \mathrm{~mm}$ Petri dishes and treated with $1.5 \mathrm{mg}$ of GAE for $6 \mathrm{~h}$. The cells were trypsinized and treated with $5 \mu \mathrm{l}$ of DAPI ( $5 \mathrm{~min}$ ) and analyzed for apoptosis, cell cycle arrest and changes in DNA content in Beckman Coulter Moflo [53, 54]. The cells which were not exposed to GAE served as the control group.

\section{Immunoblot analysis}

The cells at a concentration of $5 \times 10^{5}$ cells $/ \mathrm{ml}$ were seeded in $100 \mathrm{~mm}$ Petri dishes and incubated to attain confluence. The cellswere exposed to the inhibitory concentration of GAE $(1.5 \mathrm{mg} / \mathrm{ml})$ for $24 \mathrm{~h}$. The cells without GAE treatment represented the control group. The medium was removed and the cells were washed twice with ice-cold PBS and lysed with RIPA buffer. The cell lysate was centrifuged $(14,000 \mathrm{rpm}, 10 \mathrm{~min})$ and the supernatant was stored at $-20{ }^{\circ} \mathrm{C}$ till further use. The protein content of the cell lysate was quantified by Lowry's method. $50 \mu \mathrm{g}$ of protein was separated in $10 \%$ SDS- PAGE and the proteins were transferred onto a nitrocellulose membrane (BioRad, USA) and blocked with 5\% skim milk (BioRad, USA). Following this, the membrane was exposed to primary antibodies $\left(4{ }^{\circ} \mathrm{C}\right.$, $24 \mathrm{~h})$ against Bax (1:500 Abcam, USA) ,Bcl-2(1:500 Abcam, USA), Bcl-XL (1:500 Abcam, USA), Caspase 3 (1:200 Abcam, USA), PI3K (1:500 Abcam, USA), p PI3k(1:1000 Abcam, USA), Akt(1:500 GenetexBio, USA), p Akt(1: 1000 GenetexBio, USA) and $\beta$ actin (1:1000 1:1000 Abcam, USA). The membrane was then incubated with HRP-conjugated anti-mouse (1:2500) and anti-rabbit (1:2000) secondary antibodies for $1 \mathrm{~h}$ (RT) with continuous shaking. The protein bands were visualized using an ECL staining kit (Amersham Pharmacia Biotech, Sweden).

\section{Scratch assay}

In order to analyze the effect of GAE on cell migration, the wound healing assay was carried as previously described [55]. In brief, cells were grown in 12-well culture plates until they became $90 \%$ confluent. Following this, the cells were exposed to serum-free medium for $12 \mathrm{~h}$. The monolayers of cells were scratched with a fine micropipette tip to create a wound. The cellular debris was removed by PBS, and the cells were exposed to serum-free medium containing different concentrations of GAE $(0.1-1.5 \mathrm{mg} / \mathrm{ml})$. The migrated cells were fixed (cold 75\% methanol, $30 \mathrm{~min}$ ) and washed with ice-cold PBS. The migration of cells into the wounded area was imaged at 0 and $24 \mathrm{~h}$.

\section{Clonogenic assay}

The ability of single cells to retain their reproducing ability to develop as a colony was analyzed by the classical clonogenic assay as described earlier [56]. In brief, the cells were grown in 6 well plates until they became confluent. The cells were then exposed to different concentrations of GAE $(0.1-1.5 \mathrm{mg} / \mathrm{ml})$ for $24 \mathrm{~h}$. The medium was removed and the cells were trypsinized to obtain a single cell suspension. Five hundred cells, exposed and unexposed to GAE were seeded in 6 well plates and fresh medium was added. The plates were left undisturbed for 7 days. Later, the medium was removed and the cells were washed with PBS, stained with Trypan blue and observed under the microscope.

\section{Immunoblot analysis of MMP expression}

To determine the antimetastatic activity of GAE, the expression of matrixes, MMP2 and MMP9 were analyzed by western blot. In brief, the cells were grown in 6 well plates, treated with GAE $(1 \mathrm{mg} / \mathrm{ml})$ for $24 \mathrm{~h}$. The cells that were not exposed to GAE represented the control. The cells were lysed as mentioned previously, and the protein was isolated. The protein was analyzed for the expression of MMP2 and MMP9 in the treated and control cells.

\section{Statistical analysis}

For in vitro analysis, all experiments were done in triplicate and the data represents the mean \pm SD.

\section{Analysis of antitumor activity of GAE on A549 tumor-induced zebrafish}

Adult male Zebrafishes $(2.5 \pm 0.2 \mathrm{~cm}$ long, $1.5 \pm 0.5 \mathrm{~g})$ were induced to develop tumors as described previously with slight modifications [57]. In brief, adult Zebrafishes were injected with $5 \mu \mathrm{l}$ of A549 cells in the muscle 
region to develop tumors. After 14 days interval, the second dose of A549 cells $(5 \mu \mathrm{l})$ was injected. The fishes were maintained in a 21-l water tank, 14/10 h light and dark cycles, under normal feed for 60 days to develop tumors. The development of tumors was confirmed by dissecting the tumor-induced fish. The tumor-induced Zebrafishes were fed with GAE (15, 30, 45 and $60 \mu \mathrm{g} /$ day) for a period of 10 days. Following this treatment, the fishes were dissected and analyzed for parameters including muscle anatomy, tumor anatomy and pathology. The experiment was done in triplicate with two fishes per group for each dosage. A control without GAE treatment was also maintained.

\section{Acute and chronic toxicity analysis in zebrafish}

Adult Danio rerio were housed in pairs. Different concentrations of $\operatorname{GAE}(100,250,500 \mu \mathrm{g} /$ day $)$ were administered orally along with the fish feed. The fishes were observed for behavioral changes and for acute and chronic toxicity. The experiment was done in triplicate and a control group was maintained.

\section{Novel Tissue-Chip for drug screening}

The novel lab-on-chip technology was used to screen the efficacy of the algal extract. The Tissue -Chip is a novel platform to replace the use of animal models. In Tissue-Chip, (Refer Additional file 1) the major organs like heart, liver, skeletal muscle and brain cells are grown in a fully closed circulatory system with active physiological hormonal balance; hence the Tissue-Chip mimics the whole animal system. Further, the Tissue-Chip enables the rapid screening of compounds (24-48 h), reduces the volume of compounds for analysis, is costeffective, non-laborious and the results are comparable to whole animal models. Currently, the toxicology analysis, drug screening, kinetics, and bioequivalence are carried out independently. However, all these processes can be integrated into a single step in the Tissue-Chip platform. Therefore, in one step, ADMET (Absorption, Distribution, Metabolism, Excretion and Toxicity), drug screening and elimination of false positives can be done.

The Tissue-Chip (Pentagrit, Chennai) used for the current drug screening is a $3 \mathrm{D}$ scaffold which allows growing cells from different organs in a single chip. Adult male Zebrafish were euthanized as per guidelines. The liver, heart, muscle and brain were dissected and isolated using dissection needle. The organs were teased to obtain a single cell suspension, centrifuged at $9000 \mathrm{rpm}$ for $15 \mathrm{~min}$. The cell pellet obtained was mixed well to get a single cell suspension. $5 \mu$ of the cells from each organ was loaded to the separate scaffold provided in the Tissue-Chip and the Cells were cultured in DMEM (without glucose and with 0.01\% tetracycline) along with different concentrations of GAE $(100,250,500 \mu \mathrm{g} / \mathrm{ml})$ at $37^{\circ} \mathrm{C}$ for $48 \mathrm{~h}$.The tissue developed was removed and stained with Hematoxylin and Eosin stain and observed under the microscope for cell viability.

\section{Results \\ GAE is rich in polyphenols and flavonoids}

G. acerosa was extracted sequentially with solvents of varying polarity. Phytochemical analysis showed the abundance of compounds in ethyl acetate extract (GAE). Table 1 shows the phytochemical analysis of different solvent extracts of G.acerosa and the presence of various phytoconstituents at different concentration in the extracts.

Total polyphenols $(61.2 \mu \mathrm{g} / 100 \mathrm{mg})$ and flavonoids $(13 \mu \mathrm{g} / 100 \mathrm{mg}$ ) were highest in GAE (Fig. 1a and b). HPLC analysis confirmed the presence of 4 compounds in GAE with retention times of 15.083, 16.70, 18.086, $19.588 \mathrm{~min}$ (Fig. 1C). FTIR analysis revealed the presence of a carbonyl group $\left(1733 \mathrm{~cm}^{-1}\right)$, C-O, stretching of alcohol $\left(1045 \mathrm{~cm}^{-1}\right), \mathrm{C}-\mathrm{O}$, stretching of ether $\left(1244 \mathrm{~cm}^{-}\right.$ $\left.{ }^{1}\right)$, and $\mathrm{C}-\mathrm{O}$, stretching of acid groups $\left(2977 \mathrm{~cm}^{-1}\right)$ in GAE (Fig. 1d). The GC-MS analysis (Fig. 2) revealed the presence of fourteen compounds in GAE (Table 2).

The abundance of phytoconstituents suggested that ethyl acetate is the best- suited solvent for the extraction of algal bioactives. The results of the DPPH assay (Fig. 1e) showed that GAE has a higher antioxidant efficiency (381\%) than ascorbic acid. The antioxidant assay showed that GAE is more effective in scavenging free radicals when compared to standard ascorbic acid.

\section{GAE induces cytotoxicity in A549 cells in vitro}

In order to determine the antiproliferative activity of GAE, A549 cells were treated with increasing concentration of GAE for $24 \mathrm{~h}$ and cell death induced was measured by MTT assay. GAE induced cell death was concentration dependent. Cell viability decreased at concentrations $>1 \mathrm{mg} / \mathrm{ml}$. The inhibitory concentration, IC50 which induced 50\% cell death was identified as $1.5 \mathrm{mg} / \mathrm{ml}$ (Fig. 3a). Hence this concentration was used for further studies.

\section{GAE induces apoptosis}

In order to investigate whether the antiproliferative activity was mediated through the induction of apoptosis, A549 cells, treated with GAE $(1.5 \mathrm{mg} / \mathrm{ml}, 6 \mathrm{~h})$ were observed for changes in nuclear morphology by DAPI, PI and Annexin V staining. The characteristic features of apoptosis-like nuclear fragmentation, sub-lobed nuclei and exposure of Phosphatidyl serine were observed in GAE treated cells through fluorescent and confocal microscopy (Fig. 3b and c). As the apoptotic hallmarks were observed morphologically, flow cytometric determination of apoptosis was done with DAPI staining. The DAPI staining revealed the presence of a diploid peak, 
Table 1 Phytochemical analysis of G.acerosa

\begin{tabular}{|c|c|c|c|c|c|c|}
\hline Phytochemical & Hexane & DCM & Ethyl Acetate & Ethanol & Methanol & Water \\
\hline Tannins & - & + & +++ & ++ & +++ & - \\
\hline Alkaloids & +++ & ++ & ++ & - & - & - \\
\hline Flavonoids & + & + & +++ & +++ & ++ & ++ \\
\hline Saponins & - & - & - & - & - & - \\
\hline Phytosterol & - & +++ & +++ & +++ & +++ & - \\
\hline Glycoside & +++ & +++ & +++ & +++ & +++ & + \\
\hline Oils \& Fats & ++ & ++ & +++ & ++ & ++ & - \\
\hline Protein & - & + & + & +++ & +++ & ++ \\
\hline Carbohydrates & - & - & + & +++ & +++ & +++ \\
\hline Resins & - & - & - & ++ & ++ & - \\
\hline Coumarins & - & + & +++ & ++ & ++ & + \\
\hline Terpenoids & - & - & +++ & +++ & +++ & - \\
\hline
\end{tabular}

+ Weak $(<3 \mu \mathrm{g} / \mathrm{ml})$, ++ Moderate $(5-7 \mu \mathrm{g} / \mathrm{ml})$, +++ Strong $(>8 \mu \mathrm{g} / \mathrm{ml})$, - Absent

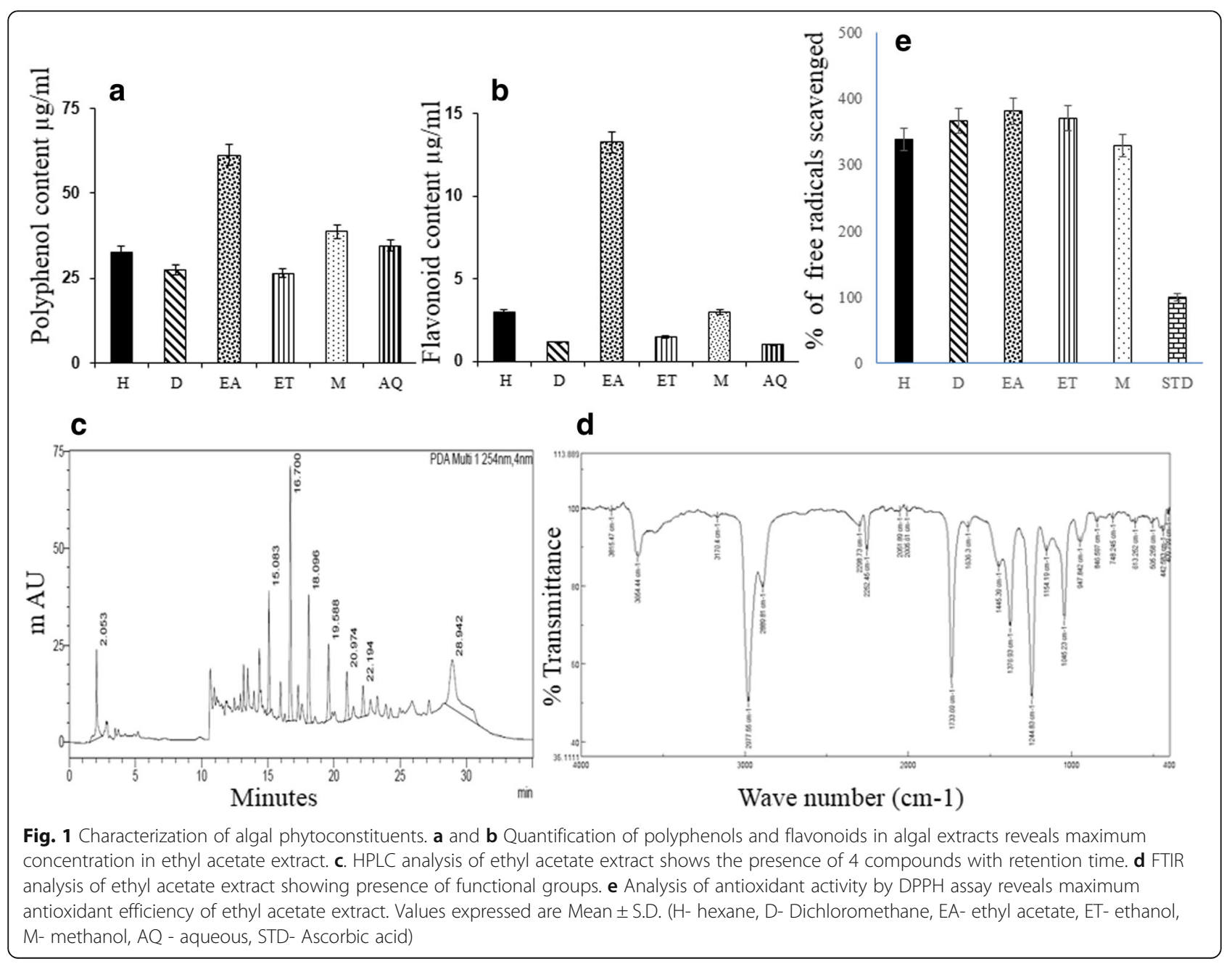




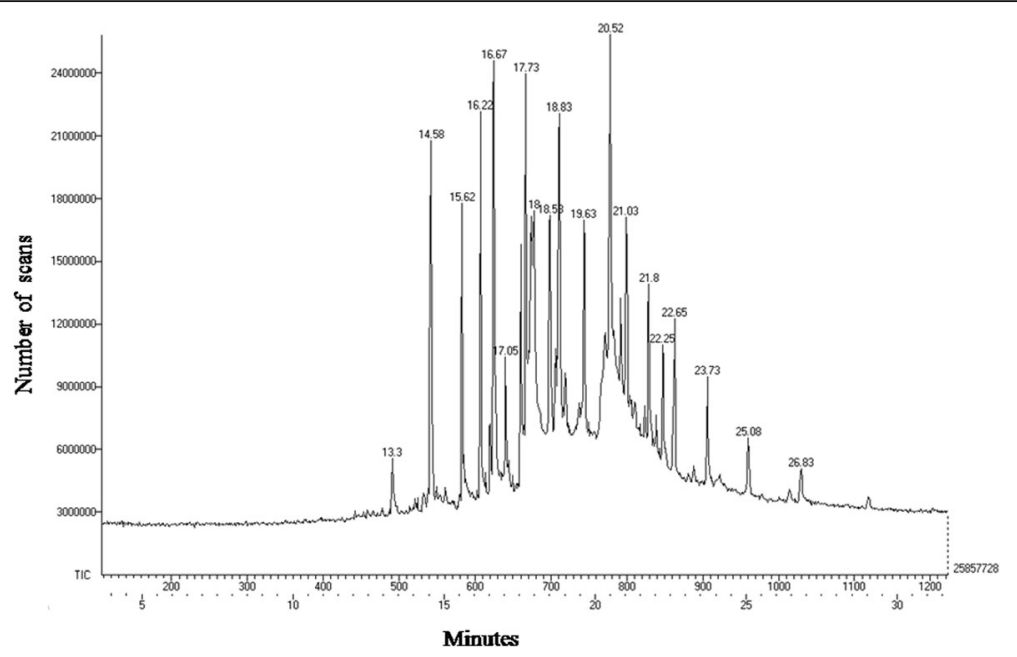

Fig. 2 GC-MS profile of GAE. The GC-MS analysis revealed the presence of various compounds with differing retention time

representing cells with fragmented DNA in the treated group (Fig. 3d). The FACS analysis thus confirmed the arrest of the cell cycle through the induction of apoptosis.

\section{GAE stimulates caspase activation}

The role of the caspase cascade in apoptosis isestablished through several studies. In order to investigate whether the induction of apoptosis is caspasedependent, the expression of caspase- 3 and 8 were analyzed in A549 cells treated with GAE. The results showed that caspase- 3 was activated as evidenced by the cleaved forms of caspase- 3 , whereas caspase- 8 expression was unaltered (Fig. 4a). The data prompts the involvement of caspase- 3 rather than caspase- 8 in the induction of apoptosis by GAE.

\section{$\mathrm{GAE}$ increases $\mathrm{Bax} / \mathrm{Bcl} 2$ ratio}

Followed by the observation of caspase- 3 in GAE induced apoptosis, the role of apoptosis regulators, namely Bax, Bcl2 and Bcl-XL was further investigated. As evidenced by western blot, the GAE treatment upregulated the expression of the pro-apoptotic protein Bax and down-regulated the expression of antiapoptotic proteins Bcl2 and Bcl-XL (Fig. 4a). The result strongly suggests that GAE induces apoptosis by altering the $\mathrm{Bax} / \mathrm{Bcl}-2$ ratio.

Table 2 GC-MS profile of G.acerosa ethyl acetate extract

\begin{tabular}{|c|c|c|c|c|c|}
\hline S. No & $\begin{array}{l}\text { Retention Time } \\
\text { (Minutes) }\end{array}$ & $\begin{array}{l}\text { PubChem } \\
\text { CID }\end{array}$ & Name of the compound & $\begin{array}{l}\text { Molecular } \\
\text { formula }\end{array}$ & $\begin{array}{l}\text { Molecular } \\
\text { weight }\end{array}$ \\
\hline 1 & 15.62 & 8217 & 1-octadecene & $\mathrm{C}_{18} \mathrm{H}_{36}$ & 252.486 \\
\hline 2 & 16.22 & 10,408 & 6,10,14-trimethyl Pentadecan-2-one & $\mathrm{C}_{18} \mathrm{H}_{36} \mathrm{O}$ & 268.485 \\
\hline 3 & 17.05 & 8181 & Methyl Palmitate & $\mathrm{C}_{17} \mathrm{H}_{34} \mathrm{O}_{2}$ & 270.457 \\
\hline 4 & 19.63 & 545,651 & 1-Heneicosyl formate & $\mathrm{C}_{22} \mathrm{H}_{44} \mathrm{O}_{2}$ & 340.592 \\
\hline 5 & 21.80 & 12,403 & Heneicosane & $\mathrm{C}_{21} \mathrm{H}_{44}$ & 296.583 \\
\hline 6 & 22.25 & $71,750,792$ & Mono(2-ethyl-6-(tetrahydropyranoxy)hexyl) Phthalate & $\mathrm{C}_{21} \mathrm{H}_{30} \mathrm{O}_{6}$ & 378.465 \\
\hline 7 & 22.65 & 12,592 & Tetracosane & $\mathrm{C}_{24} \mathrm{H}_{50}$ & 338.664 \\
\hline 8 & 23.73 & 8222 & Eicosane & $\mathrm{C}_{20} \mathrm{H}_{42}$ & 282.556 \\
\hline 9 & 26.83 & $5,365,995$ & 5 Methyl-Z,5-docosene & $\mathrm{C}_{23} \mathrm{H}_{46}$ & 322.621 \\
\hline 10 & 18.00 & 985 & Palmitic acid & $\mathrm{C}_{16} \mathrm{H}_{32} \mathrm{O}_{2}$ & 256.43 \\
\hline 11 & 13.30 & 12,395 & 1-Hexadecene & $\mathrm{C}_{16} \mathrm{H}_{32}$ & 224.432 \\
\hline 12 & 14.58 & 12,398 & n-Heptadecane & $\mathrm{C}_{17} \mathrm{H}_{36}$ & 240.475 \\
\hline 13 & 25.08 & 283,510 & 2-Methyl tricosane & $\mathrm{C}_{24} \mathrm{H}_{50}$ & 338.664 \\
\hline 14 & 16.67 & $3,072,462$ & Methyl(((2-nitro-4- (phenylmethoxy)phenyl)amino) thioxomethyl)carbamate & $\mathrm{C}_{16} \mathrm{H}_{15} \mathrm{~N}_{3} \mathrm{O}_{5} \mathrm{~S}$ & 361.372 \\
\hline
\end{tabular}



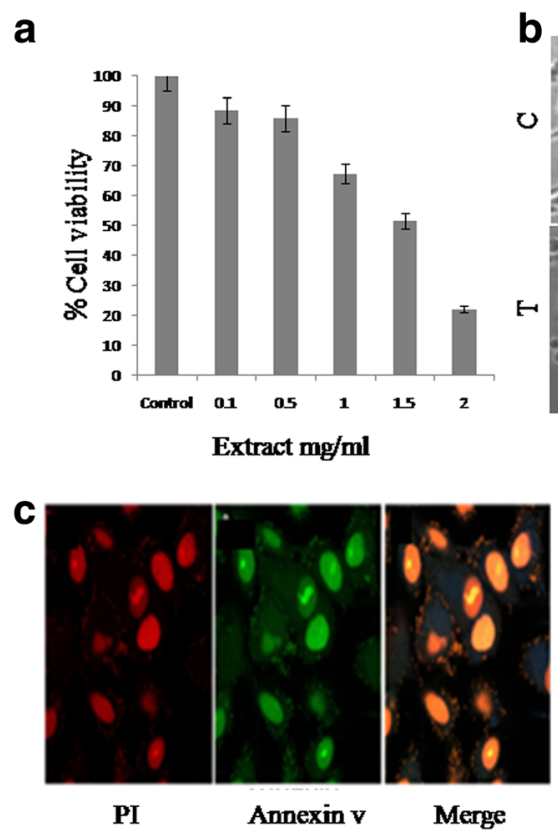

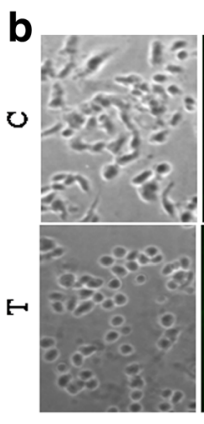

DIC

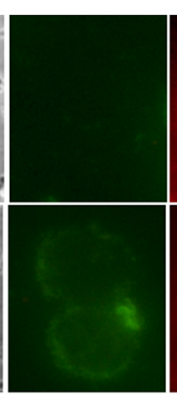

Annexin V

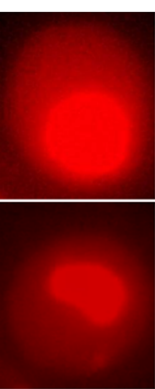

PI

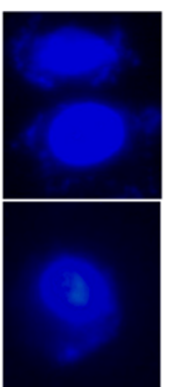

DAPI

d

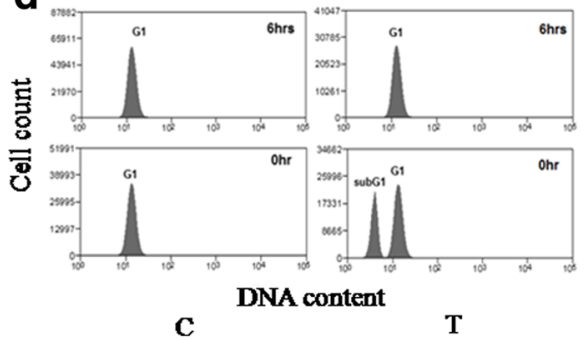

Fig. 3 In vitro analysis of anticancer activity in A549 cells. a Cytotoxicity analysis in A549 cells identifies IC50 as 1.5 mg/ml of GAE. b Fluorescent imaging with Annexin, Propidium iodide and DAPI revealed the translocation of Phosphatidyl serine to the cell membrane and nuclear fragmentation in GAE treated cells. c Confocal imaging of GAE treated cells showing nuclear fragmentation. $\mathbf{d}$ FACS analysis of Apoptosis by DAPI staining shows the emergence of apoptotic peak after $6 \mathrm{~h}$ of GAE treatment. All experiments were done in triplicate. The values represent Mean \pm SD. C-control, T-treated

\section{GAE activates GSK3 $\beta$}

In order to determine the molecular mechanism behind the alteration of $\mathrm{Bax} / \mathrm{Bcl}-2$ ratio, the expression level of GSK3 3 , a major regulator of apoptotic proteins was analyzed in GAE treated A549 cells. The results revealed that GAE treatment decreased the phosphorylation of GSK3 $\beta$, thus preventing the inactivation of GSK3 $\beta$ (Fig. 4a). The expression of the active form of GSK3 $\beta$ directly correlates to the increased Bax and decreased Bcl-2 levels.

\section{GAE affects PI3K/Akt expression}

In order to explore the underlying mechanism that contributes to the activation of GSK3 $\beta$, its direct upstream regulators, namely PI3K and Akt expression were investigated. In most human cancers the pro-survival kinase signaling pathway PI3K/Akt is activated accompanied by the inactivation of GSK3 3 . Hence the expression of PI3K and Akt in GAE treated cells was analyzed. The results showed a decrease in the phosphorylation of both the upstream targets PI3K and Akt (Fig. 4a) which in turn coincides with the increased expression of GSK3 $\beta$. These findings indicate that GAE induces apoptosis, activates GSK3 $\beta$ through the suppression of PI3K/Akt cascade in A549 cells. The protein levels were quantified and shown in Fig. 5.

\section{GAE inhibits cell migration}

In order to analyze the invasive potency of GAE, the wound healing assay was carried out. The cells treated with GAE were observed for their ability to invade into the wounded area. The results of the assay showed that the untreated cells were more efficient in closing the created wound compared to the GAE treated cells. Thus, GAE $(1 \mathrm{mg} / \mathrm{ml})$ decreased the number of cells invading the wound. The concentrations less than $1 \mathrm{mg} / \mathrm{ml}$ were not effective (Fig. 4b).

\section{GAE treatment suppresses colonization}

Metastasis is a multi-step process, involving the digestion of the ECM (Extracellular Matrix), migration and colonization of cells to distant sites. As GAE inhibited cell migration and cell proliferation, the ability of GAE on colony formation was analyzed by the clonogenic assay. The results showed that GAE inhibited the ability of individual cells to form colonies at $1 \mathrm{mg} / \mathrm{ml}$ in A549 cells, whereas the concentrations less than $1 \mathrm{mg} / \mathrm{ml}$ did not have any effect on colonization. (Fig. 4c).

\section{GAE suppresses MMP2 level}

In order to determine the antimetastatic activity of GAE, the protein from the cells was analyzed for the expression patterns of matrix metalloproteinases. The results of Western blot showed decreased expression of MMP2 
a

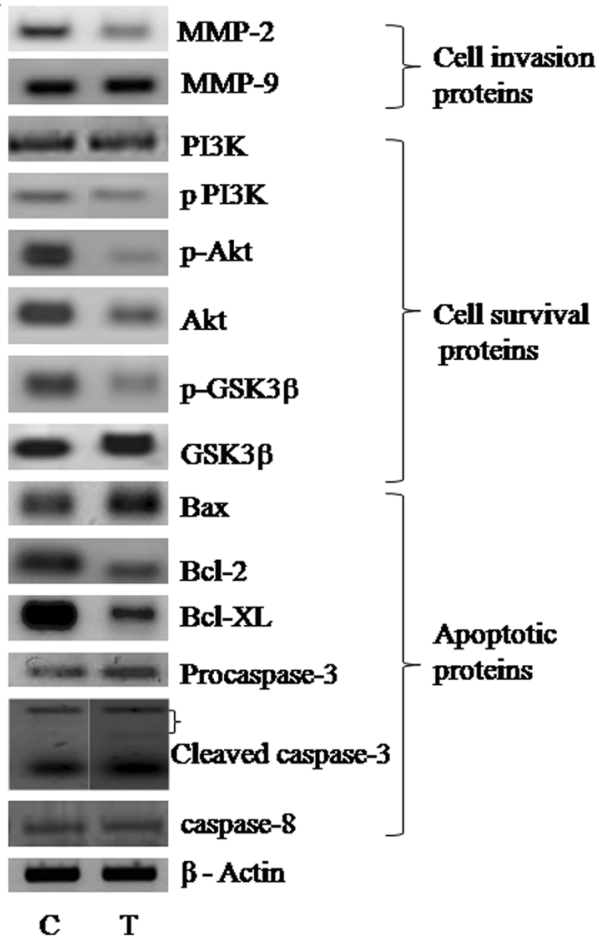

b

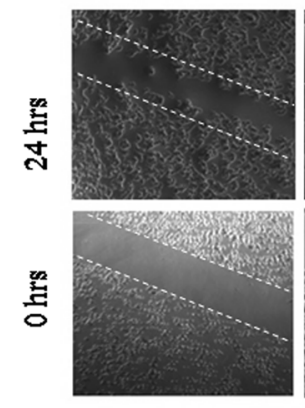

C $\mathbf{c}$

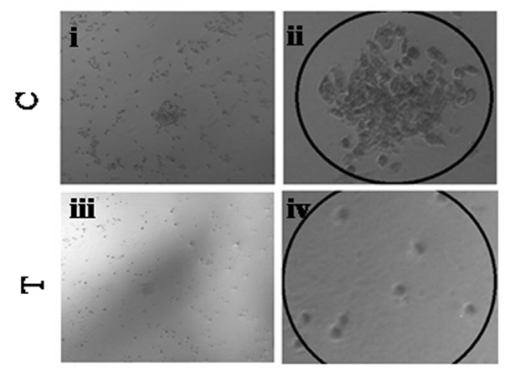

Fig. 4 Analysis of protein expression. a Western blot analysis of procaspase-3, cleaved caspase3, caspase-8, Bax, Bcl-2 and Bcl-XL, p-Akt, Akt, p-GSK3 $\beta$ and GSK3 $\beta$, PI3K, p-PI3K, MMP2 and MMP9. $\beta a c t i n$ was used to check equal loading. $\mathbf{b}$ The scratch assay shows the inhibition of cell invasion into the wound region after $24 \mathrm{~h}$ of GAE treatment $(1 \mathrm{mg} / \mathrm{ml})$. c The clonogenic assay result shows the inability of single cells to proliferate as a colony after GAE treatment (1 mg/ml). (i) Colony formed in control cells after 7 days, (ii) magnified colony of control cells, (iii) Treated cells after 7 days, (iv) treated cells magnified. C-control, T-treated

in GAE treated cells when compared to the control (Fig. 4a) however, MMP9 expression was not altered.

Thus, the results of in vitro analysis confirmed the efficiency of GAE in regulating cell proliferation through PI3K cascade and also in controlling metastasis and tumor formation in A549 cells.

\section{GAE is not toxic in vivo and in vitro}

The outcomes of the in vivo toxicology analysis showed that the major organs, including the brain, heart, muscle and liver were normal at the dosages of GAE used, both in acute and chronic studies (Fig. 6). These results were confirmed by the lab-on-chip assay where the tissues of brain, heart, liver and muscles regenerated normally till the highest dosage used $(500 \mu \mathrm{g})$. Both the in vitro and in vivo toxicology studies proved that GAE is not toxic to animals (Fig. 7).

\section{GAE inhibits tumor proliferation in vivo}

The antitumor activity of GAE was determined in vivo, using the tumor model of zebrafish. The tumor anatomy, tumor pathology and muscle pathology were analyzed by $\mathrm{H}$ \& $\mathrm{E}$ stain. The results of the histological analysis showed that the tumor control exhibited swollen muscle pathology (Fig. 8a), loss of normal cell architecture with the irregular nucleus (Fig. 8c) whereas the GAE treated group showed normal muscle pathology (Fig. 8d) and lysing tumor cells (Fig. 8f). An increase in the normal cell population was observed in the treated group $(60 \mu \mathrm{g})$ as compared to the tumor control. The other treated groups $(15,30 \& 45 \mu \mathrm{g})$ did not show any consistent change. The tumor anatomy showed a decrease in the extent of angiogenesis in the treated group as compared to the control group (Fig. 8b \& e).

\section{Discussion}

Oxidative damage by reactive oxygen species plays a major role in cancer. Intake of antioxidants can protect from oxidative stress. In the current study, GAE has exhibited higher antioxidant efficiency than ascorbic acid. An earlier study has shown that the methanol fraction of G.acerosa exhibited comparative antioxidant activity as that of Butylated Hydroxyl Toluene [58]. The current study has revealed the superiority of GAE over the methanol fraction in scavenging free radicals. Phenolics and flavonoids are excellent free radical scavengers [59]. The current study has revealed a positive correlation between the flavonoid, phenolic and antioxidant efficiency. 


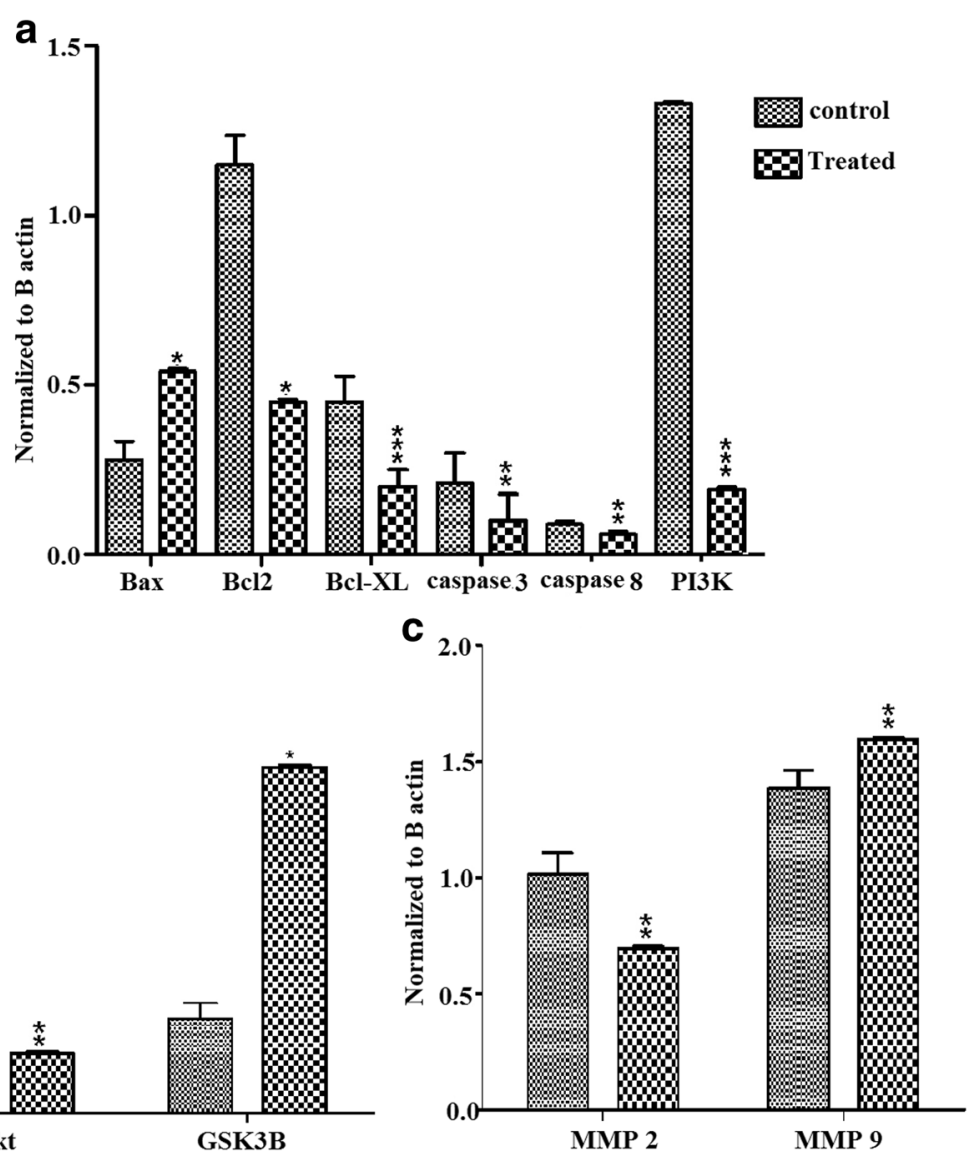

Fig. 5 Analysis of protein expression. Histogram shows the optical density of (a) Bax, Bcl2, BCl-XL, Caspase 8, Caspase 3 and ratio of phospho to total PI3K. $\mathbf{b}$ Histogram shows the optical density of phospho to total Akt, GSK3ß. $\mathbf{c}$ Histogram shows the optical density of MMP2 and MMP9. Relative expression of protein was normalized to $\beta$ actin. The density was analyzed by ImageJ software. Values represent mean $\pm S D$. ${ }^{*} p<0.1,{ }^{* *} p$ $<0.05{ }^{* * *} p<0.001$ compared to control group. C-control, T-treated

Hence it can be concluded that these components confer free radical scavenging ability to GAE.

Further, the results of the study coincide with similar studies which have reported a positive correlation between antioxidant activity, flavonoids and phenolic content [60].

Lung adenocarcinoma is the major subtype that contributes to $40 \%$ of NSCLC cases when compared to other subtypes [61]. For the current study, the A549 cells (Adenocarcinoma epithelial cells) were used to investigate the efficacy of GAE, as the A549 cells are well characterized among human lung cancer cells and serve as an established research tool to analyze the anticancer drug efficacy, permeability, immunotoxicity, apoptosis and protein expression under in vitro conditions. The anticancer activity of GAE was analyzed against different types of cancer cell lines (results are not shown) and the current study discusses the anticancer activity of GAE in A549 adenocarcinoma cell line.

The MTT assay showed that GAE exerted growth inhibitory activity in A549 cells in a concentrationdependent way. A concentration of $1.5 \mathrm{mg} / \mathrm{ml}$ induced
$50 \%$ cell death, which was identified as the inhibitory concentration (IC50). The results of the current study are comparable with a previous study, where the methanol extract of G.acerosa was shown to affect the viability of A549 cells [37-39]. Additionally, the benzene extract of G.acerosa was reported as non-cytotoxic in PBMC and did not induce mutagenicity and genotoxicity [62]. The results of these previous studies show that the algal extract is not toxic to normal cells, but can affect the viability of cancer cells.

The observation of the hallmarks of apoptosis, as documented by fluorescent, confocal microscopy and the appearance of the sub-diploid peak as evidenced from FACS analysis in GAE treated cells confirmed that cytotoxicity exerted by GAE is through the induction of apoptosis. Apoptosis or programmed cell death is activated by two major pathways [63], one involving the activating caspase- 8 and the other involving the execution caspase-3. In the current study, treatment with GAE activated Caspase- 3 and altered the $\mathrm{Bax} / \mathrm{Bcl} 2$ ratio, which suggests that apoptosis is induced by the mitochondria - 

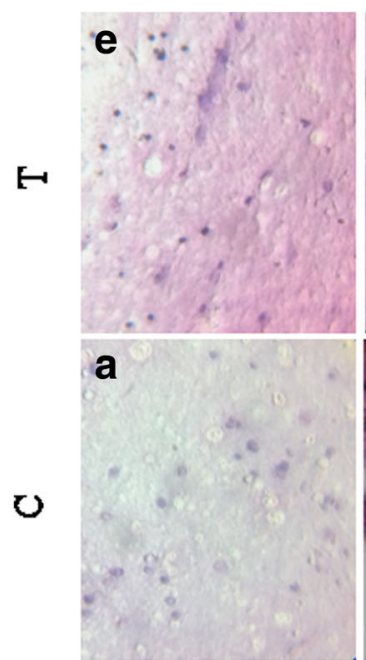

Brain
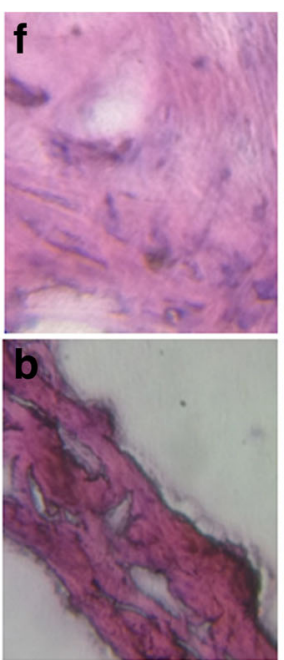

Heart
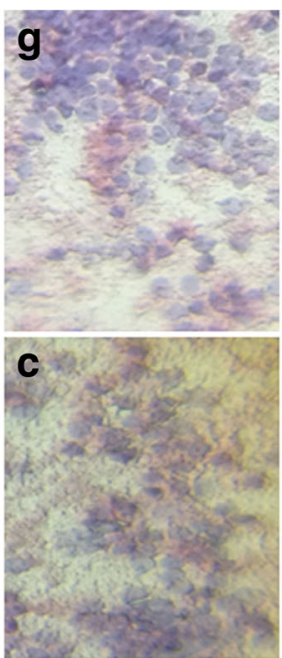

Liver
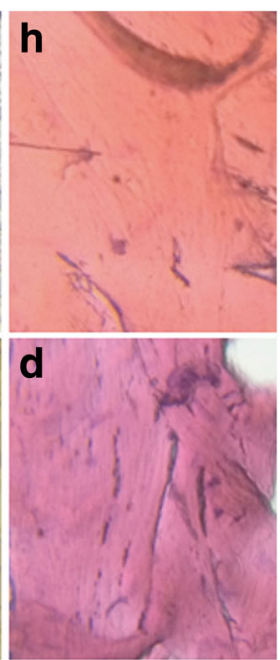

Muscle

Fig. 6 In vivo chronic toxicology analysis. a, e Shows the unaltered brain pathology of control and GAE treated Zebrafish. b, f Shows the pathology of heart muscles in control and GAE treated Zebrafish. c, g Shows the unaltered muscle pathology of control and GAE treated Zebrafish. $\mathbf{d}$, $\mathbf{h}$ Shows the pathology of liver cells in control and GAE treated Zebrafish. The pathology results confirm that GAE is not toxic to these major organs under chronic conditions. C-control, T-treated

mediated pathway. The alteration of the pro-apoptotic to anti-apoptotic protein levels strongly confirmed the involvement of GSK3 $\beta$ in the apoptotic pathway. As GSK3 $\beta$ regulates the expression of proteins in Bcl-2 family $[64,65]$, it plays a pivotal role in cell death and survival. Further, the imbalance between pro and antisurvival factors is associated with malignancy, the expression levels of GSK3 in correlation with them were investigated. The results of the current study showed that treatment with GAE inhibited the inactivation of GSK3 3 , which in turn up-regulated the Bax expression, activated caspase-3 and induced apoptosis. As the activation of GSK3 is strictly regulated by its immediate upstream targets PI3K and Akt [66], the study further investigated the expression of these pro-survival components. The results of the analysis showed that PI3K and Akt are down-regulated by GAE treatment which directly contributed to the activation of GSK3 3 . The results

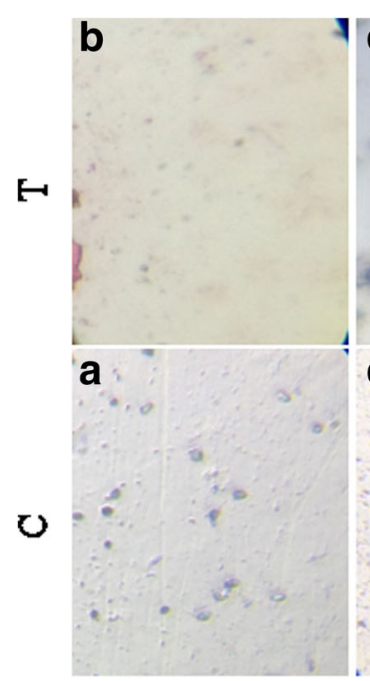

Brain

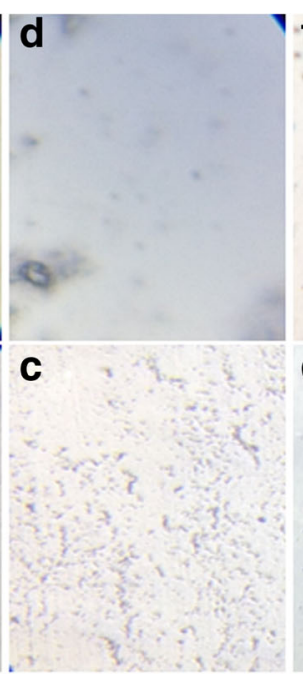

Heart

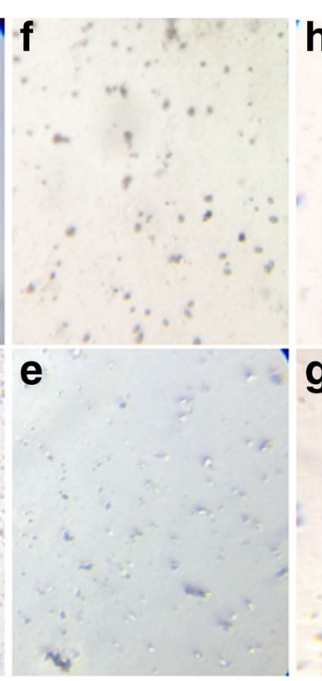

Liver

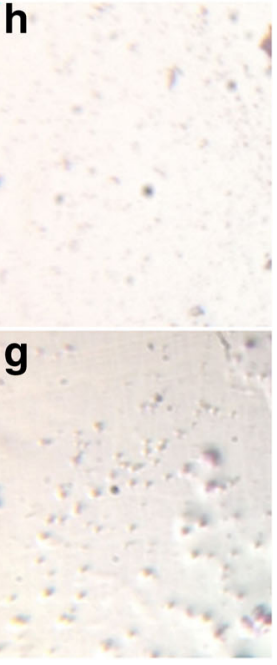

Muscle

Fig. 7 Toxicology analysis in Tissue-Chip. The pathology studies of vital organs namely brain, heart, liver and muscle were analyzed in both control (a, c, e, g) and in treated $(\mathbf{b}, \mathbf{d}, \mathbf{f}, \mathbf{h})$ tissue chip. The treatment with algal extract $500 \mu \mathrm{g}$ did not affect the tissue architecture. The results of tissue chip analysis also support GAE to be safe without toxicity. These tissues were developed and analysed for toxicity in Tissue-Chip Pentagrit, Chennai. C-control, T-treated 

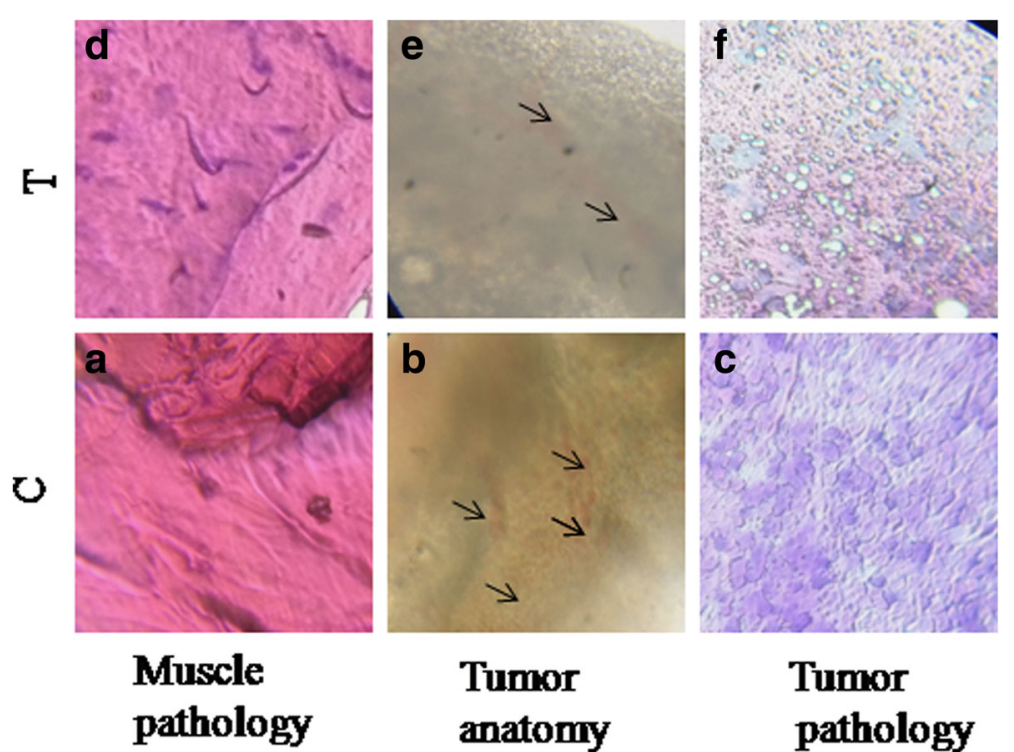

\section{Tumor anatomy}

\section{Tumor pathology}

Fig. 8 In vivo analysis of antitumor activity. $\mathbf{a}, \mathbf{b}$, c Histopathological analysis of muscle and tumor of tumor induced zebrafish. $\mathbf{d}, \mathbf{e}, \mathbf{f}$ Histopathological analysis of muscle and tumors from GAE treated tumor induced zebrafish. C-control, T-treated

of the current study are in correlation with a previous study, where the inhibition of PI3K/Akt is reported to enhance apoptosis [67]. As the constitutive expression of PI3K pathway causes inactivation of GSK3 $\beta$ and inhibition of apoptosis, GAE treatment is shown to decrease PI3K/Akt expression, activate GSK3 $\beta$ and promote apoptosis. Further, the level of GSK3 $\beta$ is considered as a probe for analyzing PI3K/Akt activity [68]. The findings of the study strongly confirm the down-regulation of PI3Kand Akt which suggests that GAE possess bioactive compounds that can serve as effective PI3K inhibitors.

Although previous studies have reported on the antiproliferative property of $G$ acerosa, ours is the first study to report on the antimetastatic property of G.acerosa. Metastasis is the major cause of cancer deaths and poor prognosis [69]. It is a complex process involving the degradation of extracellular matrix and invasion of cells into the circulation [70]. Metastasis in cancers of the lung, breast, prostate and ovary are marked by an increased expression of Matrixins or Matrix metalloproteinases (MMPs) [71-73]. MMPs play a vital role in tumor growth, proliferation, angiogenesis and invasion. The secretion and activation of MMP2 and MMP9 are linked with the degradation of ECM and promotion of tumor metastasis $[74,75]$. The cell migration assay and colony formation assays revealed the efficiency of the algal bioactives to inhibit cell invasion and prolonged proliferation and correlated with the expression of MMPS. The results revealed a significant decrease in the expression level of MMP2 in the GAE treated cells. Thus the investigation showed that the algal compounds regulate metastasis through the inhibition of MMP2 rather than
MMP9. Previous studies have reported the increased levels of MMP2 in NSCLC population and that the level of MMP2 served as an indicator of the extent of tumor metastasis [76-80]. Thus the findings of the current study are in correlation with the previous studies which have shown an increased MMP2 expression in NSCLC. Hence the outcomes of our study confirmed that the algal compounds effectively inhibited not only cell survival, but also cell migration and colonization which are the key challenges in the treatment of cancer.

Following the results of in vitro analysis, the anticancer activity of G.acerosa was determined invivo in tumor model of zebrafish. The results of the histological analysis showed an increase in the normal cell population in the treated group $(60 \mu \mathrm{g})$. The observation of lysing cells in the treated group further emphasized the antitumor efficacy of GAE. The outcomes of the in vivo study which are in correlation with the in vitro results suggested the antiproliferative activity of GAE.

The activation of Akt through PI3K is reported to confer resistance to cancer therapy and contribute to poor prognosis in cancer [81] hence down regulation of PI3K and its components are crucial in controlling cell survival and proliferation. Thus the current study has enabled toexplore the molecular mechanism by which the algal compounds can induce apoptosis and regulate the PI3K pathway in cancer. These findings may pave new ways for the effective utilization of seaweeds in the development of PI3K/Akt inhibitors for the management of cancer.

Since GAE exhibited antitumor activity in vitro, the analysis of acute and chronic toxicity was carried out. 
The results of in vivo toxicology analysis (both acute and chronic) showed that the compounds of GAE were nontoxic at the concentration used. The major organs including the brain, heart, liver and muscles showed a normal morphology as the control. Similarly in vitro toxicology analysis in Zebrafish Tissue-Chip also revealed the ability of brain, heart, liver and muscles to develop normally without any deformities. Thus the toxicology analysis further supports our study that GAE can induce apoptosis only in tumor cells by targeting PI3K without inducing any toxicity.

In addition, in the current study, the bioactives of GAE were not isolated and analyzed individually. The outcomes of the study are the combined effect of the bioactives, which can be analyzed further for their individual effects. This correlates well with the concept of traditional medicine, which indicates that the synergistic effect of all the components of an extract contributes to the maximum therapeutic effect. As natural products are multitargeted, they have good bioavailability and can neutralize any adverse effects, and hence are widely used in treating multitargeted diseases. In recent years combination therapy has gained importance in the treatment of various diseases like diabetes, cancer and cardiovascular disease, and our study is in line with this.

\section{Conclusion}

Overallthe results of the current investigation revealed the antitumor efficacy of GAE phytochemicals which need to be isolated and characterized for further development of potent PI3K inhibitors for the efficient management of cancer. The current investigations pave way for the improved utilization of marine resources which still remain as an untapped reservoir of biotherapeutics.

\section{Additional file}

Additional file 1: Image of tissue chip. (JPEG $62 \mathrm{~kb}$ )

\section{Abbreviations}

ADMET: Absorption, distribution, metabolism, excretion and toxicity; DAPI: 4',6-diamidino-2-phenylindole; DMEM: Dulbecco's modified eagle medium; FACS: Fluorescence-activated cell sorting; GAE: Gelidiella acerosa ethyl acetate extract; PI: Propidium lodide; PI3K: Phoshhotidyl inositol-3-kinase

\section{Acknowledgements}

The Research Scholar, S.M.Fazeela Mahaboob Begum would like to thank B.S.Abdur Rahman Crescent University for providing Junior Research Fellowship for her. We are thankful to Dr. Raju Saravanan, Scientist, Center for Marine Fisheries Institute, Mandapam, India for his constant support in collection and authentication of the seaweed used for the study.

\section{Funding}

The study did not receive any research funding from any agency.

\section{Availability of data and materials}

The datasets used and analyzed during the current study are available from the corresponding author on reasonable request.

\section{Authors' contributions}

SMF performed the experiment, collected and analyzed the data, KC \& BJ designed the Zebrafish work, RS edited the manuscript, $\mathrm{SH}$ designed and conceived the study. All the authors wrote and edited the manuscript. All authors read and approved the final manuscript.

\section{Ethics approval}

The Ethical clearance was granted by the Institutional Animal Ethics Committee of Pentagrit, where the work was carried out (IAEC study No: 213/GO06/IAEC).

\section{Consent for publication}

Not applicable.

\section{Competing interests}

The authors declare that they have no competing interests.

\section{Publisher's Note}

Springer Nature remains neutral with regard to jurisdictional claims in published maps and institutional affiliations.

\section{Author details}

${ }^{1}$ School of Life Sciences, B.S. Abdur Rahman Crescent University, Chennai 600048, India. ${ }^{2}$ Pentagrit, Chennai 600100, India. ${ }^{3}$ School of Engineering Technology, Purdue university, West Lafayette, IN 47907, USA.

Received: 18 August 2017 Accepted: 9 March 2018

Published online: 20 March 2018

\section{References}

1. Kumar R. A phase $1 \mathrm{~b}$ trail of the combination of an all- oral regimen of capecitabine and erlotinib in advanced non small cell lung cancer in Caucasian patients. Cancer ChemotherPharmacol. 2016;77:375-83.

2. Travis WD, Brambilla E, Noguchi M, Nicholson AG, Geisinger KR, Yatabe Y, et al. International association for the study of lung cancer/american thoracic society/european respiratory society: international multidisciplinary classification of lung adenocarcinoma. J Thorac Oncol. 2011;8(2):381-5.

3. Dacic S. Molecular diagnostics of lung carcinomas. Arch Pathol Lab Med. 2011;135(5):622-9.

4. RapariaK VC, DeCamp MM, Patel JD, Mehta MP. Molecular profiling in nonsmall cell lung cancer :a step toward personalized medicine. Arch Pathol Lab Med. 2013;137:481-91.

5. Fruman DA, Meyers RE, Cantley LC. Phosphoinositide kinases. Annu Rev Biochem. 1998;67:481-507.

6. Thorpe LM, Yuzugullu H, Zhao JJ. PI3K in cancer: divergent roles of isoforms, modes of activation and therapeutic targeting. Nat Rev Cancer. 2015;15(1): $7-24$.

7. Li L, Wei XH, Pan YP, Li HC, Yang H, He QH, Pang Y, Shan Y, Xiong FX, Shao GZ, Zhou RL. LAPTM4B: anovel cancer-associated gene motivates multidrug resistance through efflux and activating PI3K/AKT signaling. Oncogene. 2010;29:5785-95.

8. Choi BH, Kim CG, Lim Y, Shin SY, Lee YH. Curcumin down-regulates the multidrug-resistance mdr1b gene by inhibiting the PI3K/Akt/NF kappa B pathway. Cancer Lett. 2008;259:111-8.

9. Foster JG, Blunt MD, Carter E, Ward SG. Inhibition of PI3K signaling spurs new therapeutic opportunities in inflammatory/ autoimmune diseases and hematological malignancies. Pharmacol Rev. 2012;64:1027-54.

10. Barrett D, Brown VI, Grupp SA, Teachey DT. Targeting the PI3K/AKT/mTOR signaling axis in children with hematologic malignancies. Paediatr Drugs. 2012;14:299-316.

11. Sheppard K, Kinross KM, Solomon B, Pearson RB, Phillips WA. Targeting PI3 kinase/AKT/mTOR signaling in cancer. Crit Rev Oncog. 2012;17:69-95.

12. Knight ZA, Shokat KM. Chemically targeting the PI3K family. Biochem Soc Trans. 2007;35:245.

13. Marone R, Cmiljanovic V, Giese B, Wymann MP. Targeting phosphoinositide 3-kinase: moving towards therapy. Biochim Biophys Acta. 2008;1784:159-85.

14. Serra V, Markman B, Scaltriti M, Eichhorn PJA, Valero V, Guzman M, Botero ML, Llonch E. NVP-BEZ235, a dual PI3K/mTOR inhibitor, prevents PI3K signaling and inhibits the growth of Cancer cells with activating PI3K mutations. Cancer Res. 2008;68(19):8022-30. 
15. Fruman DA, Cantley LC. Idelalisib - A PI3K Inhibitor for B-Cell Cancers. N Engl J Med. 2014;370(11):1061-2. https://doi.org/10.1056/NEJMe1400055.

16. Ando $Y$, Inada-Inoue $M$, Mitsuma A, Yoshino T, Ohtsu A, Suenaga N, et al. Phase Idose-escalation study of buparlisib (BKM120), an oral pan-class IPI3K inhibitor, in Japanese patients with advanced solid tumors. Cancer Sci. 2014; 105:347-53.

17. Massacesi C, Di Tomaso E, Urban P, et al. Pl3K inhibitors as new cancer therapeutics: implications for clinical trial design. OncoTargets Ther. 2016;9: 203-10. https://doi.org/10.2147/OTT.S89967.

18. Juric D, de Bono JS, LoRusso PM, Nemunaitis J, Heath El, Kwak EL, MacarullaMercadé T, Geuna E, Jose de Miguel-Luken M, Patel C, Kuida K, Sankoh S, Westin EH, Zohren F, Shou Y, Tabernero J. A first-in-human, phase I, doseescalation study of TAK-117, a selective PI3Ka isoform inhibitor, in patients with advanced solid malignancies. Clin Cancer Res. 2017;23(17):5015-23.

19. Evans CA, Liu T, Lescarbeau A, Nair SJ, Grenier L, Pradeilles JA, Glenadel Q, Tibbitts T, Rowley AM, DiNitto JP, Brophy EE, O'Hearn EL, Ali JA, Winkler DG, Goldstein SI, O'Hearn P, Martin CM, Hoyt JG, Soglia JR, Cheung C, Pink MM, Proctor UL, Palombella VJ, Tremblay MR, Castro AC. Discovery of a selective p hosphoinositide-3-kinase (PI3K)- $\gamma$ inhibitor (IPI-549) as an immunooncology clinical candidate. ACS Med ChemLett. 2016;7(9):862-7.

20. Carlino L, Rastelli G. Dual kinase-Bromodomain inhibitors in anticancer drug discovery: a structural and pharmacological perspective. Med Chem. 2016; 59(20):9305-20.

21. Heffron TP, Heald RA, Ndubaku C, Wei B, Augistin M, Do S, Edgar K, Eigenbrot C, Friedman L, Gancia E, Jackson PS, Jones G, Kolesnikov A, Lee LB, Lesnick JD, Lewis C, McLean N, Mörtl M, Nonomiya J, Pang J, Price S Prior WW, Salphati L, Sideris S, Staben ST, Steinbacher S, Tsui V, Wallin J, Sampath D, Olivero AG. The rational design of selective Benzoxazepin Inhibitors of the a-isoform of phosphoinositide 3-kinase culminating in the identification of (S)-2-((2-(1-isopropyl-1H-1,2,4-triazol-5-yl)-5,6dihydrobenzo[f]imidazo[1,2-d][1,4]oxazepin-9-yl)oxy) propanamide (GDC0326). J Med Chem. 2016;59(3):985-1002.

22. Rugo HS, Vidula N, Ma C. Improving response to hormone therapy in breast cancer: new targets, new therapeutic options. Am Soc Clin Oncol Educ Book. 2016;35:e40-54.

23. Burger JA, Tedeschi A, Barr PM, Robak T, Owen C, et al. Ibrutinib as initial therapy for patients with chronic lymphocytic leukemia. N Engl J Med. 2015; 373:2425-37. https://doi.org/10.1056/NEJMoa1509388.

24. Newman DJ, Cragg GM. Natural products as sources of new drugs over the 30 years from 1981 to 2010. J Nat Prod. 2012;75(3):311-35.

25. Haefner B. Drugs from the deep: marine natural products as drug candidates. Drug Discov Today. 2003;8(12):536-44.

26. Cragg GM, Newman DJ. Plants as a source of anti-cancer agents. Ethnopharmacol. 2005;100:72-9.

27. Harada H, Yamashita U, Kurihara E, Fukushi E, et al. Antitumor activity of palmitic acid found as a selective cytotoxic substance in marine red algae. Anticancer Res. 2002;22:2587-90.

28. Taskin E, Ozturk M, Taskin E, Kurt O. Antibacterial activities of some marine algae from the Aegean Sea (Turkey). Afr J Biotechnol. 2007;6(24):2746-51.

29. Prasad K, Siddhanta AK, Ganesan M, Ramavat BK, Jha B, Ghosh Pushpito K, et al. Agars of Gelidiella acerosa of west and southeast coasts of India. Bioresour Technol. 2007;98(10):1907-15.

30. Pandima Devi K, Suganthy N, Kesika P, Pandian SK. Bioprotective properties of seaweeds: in vitro evaluation of antioxidant activity and antimicrobial activity against food borne bacteria in relation to polyphenolic content. BMC Complement Altern Med. 2008;8-38:1-11.

31. Suganthy N, Nisha SA, Pandian SK, Devi KP. Evaluation of Gelidiella acerosa, the red algae inhabiting south Indian coastal area for antioxidant and metal chelating potential. Biomed Prev Nutr. 2013;3(4):399-406.

32. Nobel Surya Pandidurai R, Kalavathi K, Perumal P. Studies on antibacterial activity of seaweeds, Enteromorphaintestinalis(Linnaeus) and Gelidiella acerosa (Forsskal) from Puducherry and Rameswaram (southeast coast of India). Int J Pharma Bio Sci. 2014;5(1):(B)1139-47.

33. Vivek M, Kumar PS, Steffi S, Sudha S. Biogenic silver nanoparticles by Gelidiella acerosa extract and their antifungal effects. Avicenna J Med Biotechnol. 2011;3:43-8.

34. Queiroz INL, Rodrigues JAG, Quinderé ALG, Holanda ML, Pereira MG, Benevides NMB, et al. Inhibition of coagulation proteases and thrombosis and sub-chronic toxicological study of a sulfated polysaccharidic fraction from the red alga Gelidiella acerosa. Maringá,v. ActaScientiarum. Biological Sci. 2014;36-4:393-401.
35. Naqvi SWA, Solimabi S, Kamat SY, Fernandes L, Reddy CVG, Bhakuni DS, et al. Bot Mar. 1980;23:51.

36. Syad AN, Shunmugiah KP, Pandima Devi K. Assessment of anticholinesterase activity of Gelidiella acerosa: implications for its therapeutic potential against Alzheimer's disease. Evidence-Based Complement Altern Med. 2012;497242:1-8.

37. Lakmal HHC, Samarakoon KW, Lee WW, Lee JH, Abeytunga DTU, Lee HS, et al. Anticancer and antioxidant effects of selected Sri Lankan marine algae. J Natl Sci Found. 2014:42(4):315-23.

38. Duraikannu K, Shameem Rani K, Anithajothi R, Umagowsalya G, Ramakritinan CM. In- vivo anticancer activity of red algae (Gelidiella acerosa and Acanthophoraspicifera). Int J Pharm Sci Res. 2014;5(8):3347-52.

39. Murugan K, lyer W. Differential growth inhibition of cancer cell lines and antioxidant activity of extracts of red, brown, and green marine algae. In Vitro Cell Dev Biol Anim. 2013;49:324-34.

40. Ratnasooriya WD, Premakumara GA, Tillekeratne LM. Post-coital contraceptive activity of crude extracts of Sri Lankan marine red algae. Contraception. 1994;50(3):291-9.

41. Demedts IK, Vermaelen KY, Van Meerbeeck JP. Treatment of extensivestage small cell lung carcinoma: current status and future prospects. Eur Respir J. 2010;35:202-15.

42. Memmott RM, Dennis PA. The role of Akt/MTOR pathway in tobacco carcinogen - induced lung tumorogenesis. Clin Cancer Res. 2010;16:4-10.

43. Pathmanathan MK, Uthayarasa K, Jeyadevan JP, Jeyaseelan EC. In vitro antibacterial activity and phytochemical analysis of some selected medicinal plants. Int J Pharm Biol Arch. 2010;1(3):291-9.

44. Evans WC, Saunders WB. Trease and Evan's Pharmacognosy Tokyo; 2001. p. 1-579.

45. Harborne JB. Phytochemical methods: a guide to modern technique of plant analysis. London: Chapman and Hall Ltd.; 1973. p. 49-188.

46. Singleton VL, Rossi JA. Colorimetry of total phenolics with phosphomolybdicphosphotungstic acid reagents. Am J Enol Vitic. 1965;16:144-58.

47. Zhishen I, Mengcheng T, Jianming W. The determination of flavanoids contents in mulberry and their scavenging effects on super radicals. Food Chem. 1999;64:555-9.

48. Gurav N, Kardani K, Solanki B, Patel B. Quantification of phenolic compound gallic acid in polyherbal ranger capsule by high performance chromatographic method. Int J Pharm Sci Rev Res. 2014;25(31):183-7.

49. Packialakshmi N, Naziya S. Fourier transform infrared spectroscopy analysis of various solvent extracts of Caralluma fimbriyata. Asian J Biom Pharm Sc. 2014;4(36):20-5.

50. Ashok kumar R, Ramaswamy M. Phytochemical screening by FTIR spectroscopic analysis of leaf extracts of selected Indian medicinal plants. Int J Curr Microbiol App Sci. 2014;3(1):395-406.

51. Blois MS. Antioxidant determination by the use of a stable free radical. Nature. 1958;181:1199-200.

52. Mossman T. Rapid colorimetric assay for cellular growth and survival: application to proliferation and cytotoxicity assays. J Immunol Methods. 1983;65:55-63.

53. Nicoletti L, Migliorati G, Pagliacci MC, Grignani F, Riccardi C. A rapid and simple method for measuring thymocyte apoptosis by propidium iodide staining and flow cytometry. J Immunol Meth. 1991:139:271-9.

54. Dimmick I. Multiple flow cytometry applications: use of DAPI. BioMed Sci. 2011;541-3.

55. Park SY, Kim JH, Lee YJ. Surfactin suppresses TPA-induced breast cancer cell invasion through the inhibition of MMP-9 expression. Int J Oncol. 2013:42:287-96.

56. Rafehi H, Orlowski C, Georgiadis GT, et al. Clonogenic Assay: Adherent Cells. Jove. 2011;49:2573. https://doi.org/10.3791/2573.

57. Stoletov K, Klemke R. Catch of the day: zebrafish as a human cancer model. Oncogene. 2008;27:4509-20.

58. Devi KP, Suganthy N, Kesika P, Karutha Pandian S. Bioprotective properties of seaweeds: In vitro evaluation of antioxidant activity and antimicrobial activity against food borne bacteria in relation to polyphenolic content. BMC Complement Altern Med. 2008;8:38.

59. Wu C, Huang M, Lin Y, Ju H, Ching H. Antioxidant properties of Cortex fraxiniand its simple coumarins. Food Chem. 2007;104:1464-71.

60. Bouba A, Njintang YN, Scher J, Mbofung CMF. Phenolic compounds and radical scavenging potential of twenty Cameroonian spices. Agric Biol J N Am. 2010;1(3):213-24.

61. Alberg AJ, Ford JG, Samet JM. Epidemiology of lung cancer: ACCP evidence based clinical practice guidelines (2nd edition). Chest. 2007:132:29S-55S. PMID: 17873159 
62. Arif Nisha S, Pandima Devi K. Assessment of mutagenic effect of G. acerosa and S. wightii in S. typhimurium(TA 98, TA 100, and TA 1538 strains) and evaluation of their cytotoxic and genotoxic effect in human mononuclear cells: a non-clinical study. Biomed Res Int. 2014:1-8. https://doi.org/10.1155/ 2014/313942

63. David R. Mcllwain D, Berger T, Mak T. Caspase functions in Ccell death and disease. Cold Spring Harb Perspect Biol. 2013;5:a008656. https://doi.org/10. 1101/cshperspect.a008656.

64. Anagnostou V, Lowery F, Zolota V, Tzelepi V, Gopinath A, Liceaga C, et al. High expression of BCL-2 predicts favorable outcome in non-small cell lung cancer patients with non squamous histology. BMC Cancer. 2010;10:186.

65. Maurer U, Preiss F, Brauns-Schubert P, Schlicher L, Charvet C. GSK-3 - at the crossroads of cell death and survival. J Cell Sci. 2014;127:1369-78.

66. Jope RS, Yuskaitis CJ, Beurel E. Glycogen synthase kinase-3 (GSK3): inflammation, diseases, and therapeutics. Neurochem Res. 2007:32:577-95.

67. Kurosu T, Nagao T, Wu N, Oshikawa G, Miura O. Inhibition of the PI3K/Akt/ GSK3 pathway downstream of BCR/ABL, Jak2-V617F, or FLT3-ITD downregulates DNA damage-induced Chk1 activation as well as G2/M arrest and prominently enhances induction of apoptosis. PLoS ONE. 2013; 8(11):e79478. https://doi.org/10.1371/journal.pone.0079478.

68. Kitagishi Y, Nakanishi A, Ogura A, Matsuda S. Dietary regulation of PI3K/AKT/ GSK-33 pathway in Alzheimer's disease. Alzheimers Res Ther. 2014;6:35.

69. Mehlen P, Puisieux A. Metastasis: a question of life or death. Nat Rev Cancer 2006:6:449-58.

70. John A, Tuszynski G. The role of matrix metalloproteinases in tumor angiogenesis and tumor metastasis. Pathol Oncol Res. 2001;7:14-23.

71. Ohbayashi H. Matrix metalloproteinases in lung diseases. Curr Protein Pept Sci. 2009:3:409-21.

72. Kim SJ, Rabbani ZN, Dewhirst MW, Vujaskovic Z, Vollmer RT, Schreiber EG, Oosterwijk E, Kelley MJ. Expression of HIF-1, CA IX, VEGF, and MMP-9 in surgically resected non-small cell lung cancer. Lung Cancer. 2005;49:325-35.

73. Schmalfeldt B, Prechtel D, Harting K, Spathe K, Rutke S, Konik E, Fridman R, Berger U, Schmitt M, Kuhn W, Lengyel E. Increased expression of matrix metalloproteinases MMP-2, MMP-9, and the urokinase-type plasminogen activator is associated with progression from benign to advanced ovarian cancer. Clin Cancer Res. 2001;7:2396-404.

74. Sheen-Chen SM, Chen HS, Eng HL, Sheen CC, Chen WJ. Serum levels of matrix metalloproteinase 2 in patients with breast cancer. Cancer Lett. 2001; 173:79-82.

75. Coussens LM, Fingleton B, Matrisian LM. Matrix metalloproteinase inhibitors and cancer: trials and tribulations. Science. 2002;295:2387-92.

76. Egeblad $M$, Werb Z. New functions for the matrix metalloproteinases in cancer progression. Nat Rev Cancer. 2002;2:161-74.

77. Iniesta P, Moran A, Juan C, Gomez A, Hernando F, Garcia-Aranda C, Frias C, Antonio Diaz-Lopez A, Rodriguez-Jimenez F, Balibrea J, Benito M. Biological and clinical significance of MMP-2, MMP-9, TIMP-1 and TIMP-2 in non-small cell lung cancer. Oncol Rep. 2007;17:217-23.

78. CB G, Wang S, Deng C, Zhang DL, Wang FL, Jin XQ. Relationship between matrix metalloproteinase 2 and lung cancer progression. Mol Diagn Ther. 2007;11(3):183-92

79. Zhang L, Li N, Yan HC, Jiang H, Fang XJ. Expression of novel CD44st and MMP2 in NSCLC tissues and their clinical significance. Oncol Res Treat. 2017; 40:192-6.

80. Leinonen T, Pirinen R, Böhm J, Johansson R, KosmaVM. Increased expression of matrix metalloproteinase-2 (MMP-2) predicts tumour recurrence and unfavourable outcome in non-small cell lung cancer. Histol Histopathol. 2008;23(6):693-700

81. Sarbassov DD, Guertin DA, Ali SM, Sabatini DM. Phosphorylation and regulation of Akt/PKB by the Rictor-mTOR complex. Science. 2005;307:1098-101. https://doi.org/10.1126/Science.1106148.

\section{Submit your next manuscript to BioMed Central and we will help you at every step:}

- We accept pre-submission inquiries

- Our selector tool helps you to find the most relevant journal

- We provide round the clock customer support

- Convenient online submission

- Thorough peer review

- Inclusion in PubMed and all major indexing services

- Maximum visibility for your research

Submit your manuscript at www.biomedcentral.com/submit
Biomed Central 